\title{
HUBUNGAN POLA ASUH ORANG TUA DENGAN PERKEMBANGAN BAHASA \\ ANAK PRASEKOLAH USIA 4-5 TAHUN \\ (di TK An Nidhom Desa Bangsongan Kabupaten Kediri)
}

Yunda Dwi Jayanti ${ }^{1}$, Lorenz Ari Ambar Wati ${ }^{2}$

Akademi Kebidanan Dharma Husada Kediri Jawa Timur

\begin{abstract}
ABSTRAK
Pola asuh orang tua merupakan cara orang tua mengarahkan anak, bagaimana mereka mendidik dan mengajarkan pada anak segala hal. Perkembangan bahasa pada anak sangat dipengaruhi adanya hubungan yang sehat antara orang tua dengan anak. Terjadinya keterlambatan berbahasa pada anak mengakibatkan anak menjadi sulit bersosialisasidengan teman sebaya maupun lingkungan sekitar. Tujuan penelitian ini untuk mengetahui hubungan antara pola asuh orang tua dengan perkembangan bahasa anak prasekolah usia 4-5 tahun.

Desain penelitian yang digunakan yaitu korelasional dengan pendekatan cross sectional. Dengan menggunakan teknik total sampling, populasi dan sampel sejumlah 38 responden ibu dan anak prasekolah usia 4-5 tahun. Variabel yang digunakan variabel independen yaitu polaasuh orang tua dan variabel dependen yaitu perkembangan bahasa anak prasekolah usia 4-5 tahun. Penelitian dilakukan tanggal 7-8 mei 2014. Data diperoleh dari kuesioner dan cheklist DDST dan pengolahan data meliputi (editing, coding, scoring, tabulating)kemudian di analisa dengan chi square.

Hasil penelitian menunjukkan bahwa dari 38 responden diperoleh 19 responden (50\%) menggunakan pola asuh demokratis dalam mengasuh anaknya dan 19 anak (50\%) perkembangan bahasanya normal. Berdasarkan hasil uji statistik chi square diperoleh hasil $x^{2}$ hitung $(18,13)>x^{2}$ tabel $(9,49)$. Sehingga dapat disimpulkan bahwa H1 diterima yang berarti ada hubungan pola asuh orang tua dengan perkembangan bahasa anak prasekolah usia 4-5 tahun.

Pola asuh orang tua yang sesuai dalam mengasuh anak dapat mengurangi terjadinya resiko keterlambatan perkembangan bahasa pada anak prasekolah usia 4-5 tahun. Sehingga orang tua perlu menerapkan pola asuh yang sesuai pada anaknya pada situasi tertentu.
\end{abstract}

\section{Kata kunci : Pola Asuh Orang Tua, Perkembangan Bahasa}




\section{PENDAHULUAN}

Menurut IDAI (2002), Perkembangan adalah bertambahnya kemampuan dan struktur/fungsi tubuh yang lebih kompleks dalam pola yang teratur, dapat diperkirakan, dan diramalkan sebagai hasil dari proses diferensiasi sel, jaringan tubuh, organ-organ, dan sistemnya yang terorganisasi (Nursalam,2005:33).

Pada perkembangan bahasa anak prasekolah diawali mampu menyebutkan hingga empat gambar, menyebutkan satu hingga dua warna, menyebutkan kegunaan benda, menghitung mengartikan dua kata, mengerti empat kata depan, mengerti beberapa kata sifat dan sebagiannya, menggunakan bunyi untuk mengidentifikasi objek, orang dan aktivitas menirukan berbagai bunyi kata, memahami arti larangan, berespons terhadap panggilan dan orang-orang anggota keluarga dekat (Hidayat,2005:26).

Tahap perkembangan dan kemampuan bahasa anak di usia prasekolah sangat penting. Mengingat perkembangan bahasa anak terjadi paling cepat di antara usia 2 - 5 tahun. Perbendaharaan kata bertambah dari 50 - 100 sampai 2000 lebih. I 1 le paling kritis untuk perkembangan ra terjadi antara usia 2-4 tahun. Kemampuan bahasa merupakan indikator seluruh perkembangan anak (Hayati,2013).

Prevalensi keterlambatan perkembangan berbahasa di Indonesia belum pernah diteliti secara luas. Kendalanya dalam menentukan kriteria keterlambatan perkembangan berbahasa. Data di Departemen Rehabilitasi Medik RSCM tahun 2006, dari 1125 jumlah kunjungan pasien anak terdapat $10,13 \%$ anak yang didiagnosis keterlambatan bicara dan

Keterlambatan bahasa pada anak prasekolah dapat mengakibatkan anak menjadi sulit bersosialisasi dengan teman sebaya maupun lingkungan sekitar. Keterlambatan bicara dan bahasa juga menjadi hambatan anak untuk mengekspresi emosi, pikiran, pendapat dan keinginannya (Hayati,2013). Anak juga akan mengalami kesulitan belajar saat mereka pada usia sekolah. Kesulitan dalam membaca dan menulis akan menyebabkan pencapaian akademik yang kurang secara menyeluruh, dan ini dapat berlanjut sampai usia dewasa muda. Selanjutnya orang dewasa dengan pencapaian akademik yang rendah akibat keterlambatan bicara dan bahasa ini akan mengalami masalah perilaku dan penyesuaian psikososial (Judarwanto,2012).

Melihat sedemikian besar dampak yang ditimbulkan akibat keterlambatan bahasa pada anak usia pra sekolah maka sangatlah penting untuk mengoptimalkan proses perkembangan bahasa anak pada periode ini. Deteksi dini keterlambatan bicara dan gangguan bicara adalah tindakan yang tidak kalah penting untuk menilai tingkat perkembangan bahasa anak. Deteksi awal adanya keterlambatan perkembangan bahasa akan membantu dalam mengatasi keterlambatan bahasa pada anak usia pra sekolah sehingga dapat meminimalkan kesulitan dalam proses belajar anak tersebut saat memasuki usia sekolah. Beberapa ahli, perkembangan bahasa dan bicara dipakai sebagai indikator perkembangan anak secara keseluruhan, termasuk kemampuan kognisi dan kesuksesan dalam proses belajar di sekolah. Hasil studi longitudinal menunjukkan bahwa keterlambatan perkembangan berbahasa berkaitan dengan intelegensi dan membaca di kemudian hari (Judarwanto,2012).

Berdasarkan studi pendahuluan yang dilakukan tanggal 14 april 2014 di TK An Nidhom, terhadap anak prasekolah yang mengalami keterlambatan perkembangan bahasa dari 10 anak prasekolah yang diteliti 5 anak masuk dalam perkembangan bahasa baik, 4 anak perkembangan bahasa kurang dan 1 anak mengalami perkembangan bahasa cukup. Dari data diatas menunjukkan bahwa kejadian keterlambatan bahasa masih tinggi pada anak prasekolah. Dan dari wawancara dengan orang tua terdapat 4 orang menganut pola asuh demokratis, 3 orang 
menganut pola asuh otoriter dan 3 lainnya permisif.

\section{METODE}

. Pada penelitian ini peneliti menggunakan desain penelitian korelasional. penelitian korelasional dalah penelitian yang bertujuan untuk mengetahui adanya hubungan korelatif antar variabel. pendekatannya menggunakann cross sectional.

Penelitian ini dilakukan untuk mencari hubungan pola asuh orang tua dengan perkembanagan bahasa anak prasekolah usia 4-5 tahun di TK An Nidhom.

Pada penelitian ini populasinya Semua orang tua dan anak usia 4-5 tahun di TK An Nidhom, Kecamatan Kayen Kidul, Kabupaten Kediri sebanyak 38 orang.

Pada penelitian ini sampel yang digunakan adalah Semua orang tua dan anak usia 4-5 tahun di TK An Nidhom di Desa Basongan Kecamatan Kayen Kidul Kabupaten Kediri sebanyak 38 0rang.

Pada penelitian ini, teknik sampling yang digunakan adalah total sampling yaitu suatu teknik pengambilan sampel dengan mengambil semua anggota populasi menjadi sampel. Pada penelitian ini variabel independennya adalah pola asuh orang tua di TK An Nidhom Desa Basongan Kecamatan Kayen Kidul Kabupaten Kediri. Pada penelitian ini variabel independennya adalah perkembangan bahasa anak usia prasekolah di TK An Nidhom Desa Basongan, Kecamatan Kayen Kidul, Kabupaten Kediri.

\section{HASIL}

a. Karakteristik responden berdasarkan tingkat pendidikan

Tabel 1: Karakteristik Responden Berdasarkan Tingkat Pendidikan Di Tk An Nidhom Desa Bangsongan Kecamatan Kayen Kidul Kabupaten Kediri

\begin{tabular}{clcc} 
No & Pendidikan & Frekuensi (f) & Prosentase (\%) \\
\hline 1 & Tidak sekolah & 0 & 0 \\
\hline 2 & SD & 2 & 5,26 \\
\hline 3 & SMP & 11 & 28,95 \\
\hline 4 & SMA & 16 & 42,10 \\
\hline 5 & Perguruan Tinggi & 9 & 23,69 \\
\hline Jumlah & 38 & 100
\end{tabular}

Dari tabel 1 menunjukkan dari 35 responden yang diteliti didapatkan 16 responden $(42,1 \%)$ berpendidikan SMA/Sederajat. Sedangkan 2 responden $(5,2 \%)$ berpendidikan $\mathrm{SD} /$ Sederajat.

b. Karakteristik responden berdasarkan pekerjaan 
Tabel 2: Karakteristik Responden Berdasarkan Pekerjaan Di Tk An Nidhom Kecamatan Kayen Kidul Kabupaten Kediri

\begin{tabular}{llcc} 
No & Pekerjaan & Frekuensi (f) & Prosentase (\%) \\
\hline 1 & IRT & 25 & 65,78 \\
\hline 2 & Petani & 5 & 13,16 \\
\hline 3 & swasta/wiraswasta & 5 & 13,16 \\
\hline 4 & PNS & 3 & 7,90 \\
\hline \multicolumn{2}{l}{ Jumlah } & 38 & 100
\end{tabular}

Dari tabel 2 menunjukkan dari 35 responden yang diteliti didapatkan 25 responden $(65,7 \%)$ bekerja sebagai Ibu Rumah Tangga. Sedangkan 3 responden (7,9\%) bekerja sebagai PNS.

c. Karakteristik responden berdasarkan umur

Tabel 3: Karakteristik Responden Berdasarkan Umur Di TK An Nidhom Desa Bangsongan Kecamatan Kayen Kidul Kabupaten Kediri

\begin{tabular}{cccc} 
No & Umur & Frekuensi (f) & Prosentase (f) \\
\hline 1 & $<20$ tahun & 2 & 5,25 \\
\hline 2 & $21-35$ & 12 & 31,58 \\
\hline 3 & $36-40$ & 17 & 44,75 \\
\hline 4 & $>40$ & 7 & 18,42 \\
\hline & Jumlah & 38 & 100
\end{tabular}

Dari tabel 3 menunjukkan dari 35 responden yang diteliti didapatkan 17 orang reesponden $(44,75 \%)$ berumur antara 36-40 tahun. Dan sebanyak 2 orang responden $(5,25 \%)$ berumur $<20$ tahun.

Penelitian yang dilakukan terhadap 38 responden yang terdiri dari orang tua dan anak prasekolah pada tanggal 1-14 mei 2014, setelah dilakukan pengolahan data primer dapat dijelaskan dalam hasil penelitian sebagai berikut:

a. Pola Asuh Orang Tua Pada Anak Prasekolah Usia 4-5 Tahun

Tabel 4 : Distribusi Frekuensi Pola Asuh Orang Tua Pada Anak Prasekolah Usia 4-5 Tahun Di Tk An Nidhom Desa Bangsongan Kecamatan Kayen Kidul Kabupaten Kediri

\begin{tabular}{clcc} 
No & Pola Asuh & Frekuensi (f) & Prosentase (\%) \\
\hline 1 & Otoriter & 8 & 21,05 \\
\hline 2 & Permisif & 11 & 28,95 \\
\hline 3 & Demokratis & 19 & 50,00 \\
\hline & Jumlah & 38 & 100
\end{tabular}

Berdasarkan Tabel 4 diatas tentang pola asuh orang tua pada anak pra sekolah usia 4-5 tahun Di Tk An Nidhom Desa Bangsongan Kecamatan Kayen Kidul Kabupaten Kediri, menunjukkan bahwa dari 38 responden yang mempunyai pola asuh demokratis sebanyak 19 responden $(50 \%)$. dan sebanyak 8 orang responden $(21,05 \%)$ dengan pola asuh otoriter.

b. Perkembangan Bahasa Anak Prasekolah Usia 4-5 Tahun 
Tabel 5: Distribusi Frekuensi Perkembangan Bahasa Anak Prasekolah Usia 4-5 Tahun Di Tk An Nidhom Desa Bangsongan Kecamatan Kayen Kidul Kabupaten Kediri

\begin{tabular}{clcc} 
No & Perkembangan Bahasa & Frekuensi (f) & Prosentase (\%) \\
\hline 1 & Normal & 19 & 50,00 \\
\hline 2 & Suspec & 14 & 36,84 \\
\hline 3 & Untesable & 5 & 13,16 \\
\hline & Jumlah & 38 & 100
\end{tabular}

Berdasarkan tabel .5 diatas tentang perkembangan bahasa anak prasekolah usia 4-5 tahun di Tk An Nidhom Deasa Bangsongan Kecamatan Kayen Kidul Kabupaten Kediri, menunjukkan bahwa dari 38 anak yang perkembangan bahasanya normal sebanyak 19 anak (50\%). dan terdapat 5 anak (13,16\%) perkembangan bahasanya untesable.

c. Tabulasi Silang Hubungan Pola Asuh Orang Tua Dengan Perkembangan Bahasa Anak Prasekolah Usia 4-5 Tahun Di Desa Bangsongan Kecamatan Kayen Kidul Kabupaten Kediri

Tabel 6: Tabulasi Silang Hubungan Pola Asuh Orang Tua Dengan Perkembangan Bahasa Anak Prasekolah Usia 4-5 Tahun Di Tk An Nidhom Desa Bangsongan Kecamatan Kayen Kidul Kabupaten Kediri

\begin{tabular}{|c|c|c|c|c|c|c|c|c|}
\hline \multirow{3}{*}{ No } & \multirow{3}{*}{ Pola asuh } & \multicolumn{6}{|c|}{ Perkembangan Bahasa } & \multirow{3}{*}{ Jumlah } \\
\hline & & \multicolumn{2}{|c|}{ Normal } & \multicolumn{2}{|c|}{ Suspec } & \multicolumn{2}{|c|}{ Untesable } & \\
\hline & & $\mathrm{F}$ & $\%$ & $\mathrm{f}$ & $\%$ & $\mathrm{~F}$ & $\%$ & \\
\hline 1 & Otoriter & 4 & 21,05 & 1 & 7,14 & 3 & 60,00 & 8 \\
\hline 2 & Permisif & 3 & 15,79 & 6 & 42,86 & 2 & 40,00 & 11 \\
\hline \multirow[t]{2}{*}{3} & Demokratis & 12 & 63,16 & 7 & 50,00 & 0 & 0 & 19 \\
\hline & Jumlah & 19 & 100 & 14 & 100 & 5 & 100 & 38 \\
\hline
\end{tabular}

chi square $x^{2}$ hitung $=18,13 x^{2}$ tabel $=9,49 \alpha 0,05$

Data yang terkumpul dari 38 responden orang tua dan anak prasekolah usia 4-5 tahun, kemudian di uji dengan korelasi chi square, didapat hasil $x^{2}$ hitung sebesar 18,13 dengan interval kepercayaan $95 \%$. hasil $x^{2}$ hitung ternyata lebih besar dari $x^{2}$ tabel yaitu $18,13>9,49$.

\section{DISKUSI}

Pada sub bab ini, peneliti akan membahas hasil penelitian tentang hubungan pola asuh orang tua dengan perkembangan bahasa anak prasekolah usia 4-5 tahun di Tk An Nidhom Desa Bangsongan Kecamatan Kayen Kidul Kabupaten Kediri. Pengambilan data dilakukan pada tanggal 1 sampai 14 mei 2014 dengan jumlah sampel 38 orang responden dari orang tua dan 38 responden anak pra sekolah.

\section{Pola Asuh Orang Tua Pada Anak Pra Sekolah Usia 4-5 Tahun}

Berdasarkan hasil penelitian tentang pola asuh orang tua pada anak prasekolah usia 4-5 tahun, dari 38 responden pada tabel 4 dapat dijelaskan bahwa sebagian besar responden menganut pola asuh demokratis sebanyak 19 orang responden 
$(50 \%)$, terdapat 11 orang responden dengan pola asuh permisif $(28,95 \%)$, serta 8 orang responden dengan pola asuh demokratis $(21,05 \%)$.

Menurut Casmini (2007), pola asuh orang tua adalah bagaimana orang tua memperlakukan anak, mendidik, membimbing, dan mendisiplinkan anak dalam mencapai proses kedewasaan hingga pada upaya pembentukan normanorma yang diharapkan masyarakat pada umumnya. Terdapat 3 macam pola asuh yang diterapkan dalam mengasuh anak di rumah yaitu otoriter, permisif dan demokratis (Septiari, 2012:162). Pola asuh ini akan menghasilkan anak yang mempunyai kompetensi sosial dan rasa percaya diri yang tinggi, kemampuan komunikasi baik, kemampuan kognitif tinggi, kreatif, dan memiliki keceerdasan majemuk (Soetjiningsih, 2014:229).

Pola asuh orang tua yang diterapkan dalam mengasuh anak akan mempengaruhi perkembangan anak kedepannya. Karena anak akan terbiasa dengan lingkungan yang dirasakan sejak kecil. Salah satu hal yang menyebabkan pola asuh demokratis dipilih sebagian besar orang tua, karena dengan pola asuh demokratis orang tua melibatkan anak sepenuhnya dalam berpendapat. Orang tua tidak beranggapan bahwa anak akan sepenuhnya dituntun oleh orang tua, disini anak juga diajak berdiskusi. Dengan pola asuh seperti ini bisa menyeimbangkan pemikiran, sikap dan tindakan antara anak dan orang tua. Orang tua dengan pola asuh demokratis menghargai individualitas anak tetapi juga menekankan batasan sosial. Dalam pola asuh ini orang tua aktif mengajak bicara anak karena orang tua berusaha melatih anak untuk berdiskusi dan berfikir. Sehingga anak terbiasa terlatih untuk memecahkan masalah yang dialaminya. Dengan pola asuh yang seperti ini tanpa disadari orang tua telah memberikan stimulasi-stimulasi perkembangan khususnya perkembangan bahasa.
Hal ini berbeda dengan dua tipe pola asuh lainnya yaitu permisif dan otoriter. Pada pola asuh permisif orang tua lebih sabar, responsif dan sedikit memberi tuntutan pada anak-anaknya. Pada pola asuh permisif orang tua seringkali menyetujui terhadap semua dengan tuntutan dan kehendak anaknya. Pola asuh permisif cenderung memanjakan anak, orang tua mewujudkan semua keinginan anak tanpa mempedulikan hal lainnya. Bila anak mampu memanfaatkan dengan baik pola asuh yang diberikan orang tua maka anak akan menjadi individu yang dewasa, kreatif dan inovatif meminta sesuatu untuk mengembangkan kreativitasnya orang tua akan berusaha untuk mewujudkannya. Orang tua pada pola asuh ini sangat menyayangi anaknya karena orang tua tidak ingin melihat anaknya menangis. Meskipun seorang anak meminta suatu hal yang tidak sesuai orang tua akan berusaha mewujudkannya. Karena pada pola asuh ini orang tua akan menuruti semua kemauan anak termasuk kemauan anak dalam memperdalam hobi. Sehingga, jika anak tidak menggunakan kesempatan ini dengan kurang baik, maka mereka akan cenderung melanggar aturan dan norma-norma yang ada.

Berbeda dengan pola asuh otoriter, pada pola asuh otoriter yang pada penelitian ini hanya dipilih sebagian kecil orang tua sebenarnya merupakan pola asuh orang tua yang menuntut dan mengendalikan anak sesuai dengan kehendak orang tua. Dalam pola asuh ini anak harus menurut kepada orang tua, dan anak tidak boleh mengeluarkan pendapat.

Pola asuh yang diterapkan orang tua dipengaruhi oleh beberapa faktor yaitu salah satunya umur. Berdasarkan tabel 3 menunjukkan sebagian besar usia responden 36-40 tahun yaitu sebanyak 17 orang responden (44,75\%). Sedangkan usia 21-35 tahun sebanyak 
12 responden $(31,6 \%)$. Lalu usia $>40$ tahun sebanyak 7 responden $(18,4 \%)$ dan pada usia $<20$ tahun sebanyak 2 responden $(5,25 \%)$.

Menurut Supartini (2004), usia merupakan salah satu faktor yang mempengaruhi kesiapan orang tua dalam menjalankan peran pengasuhan terhadap anaknya. Usia yang terlalu muda dapat menyebabkan orang tidak dapat melaksanakan peran pengasuhan secara optimal.

Dari uraian di atas maka dapat diketahui bahwa faktor usia merupakan salah satu penentu dalam penerapan pola asuh orang tua. Sebab usia juga mempengaruhi kematangan seseorang dalam mengasuh anak, karena orang tua dengan usia dewasa sudah berpengalaman dalam mengasuh anak berbeda dengan orang tua dengan usia muda, kebanyakan orang tua dengan usia muda belum berpengalaman dalam mengasuh anak, karena baru kali pertama mereka mempunyai anak. Selain itu kematangan usia akan membuat orang tua berfikir dewasa dan lebih matang dalam mengasuh anak.Orang tua menjadi lebih sabar dalam menghadapi kelakuan anak yang terkadang menjengkelkan dan membuat geram. Namun, dengan kematangan usia orang tua, akan cenderung menghadapinya dengan memberikan pengertian dan bisa membuat anak berfikir mana yang benar dan salah.

Kematangan usia orang tua membuat orang tua tau cara pengembangan pola asuh yang akan diterapkan. Sehingga orang tua lebih bisa mengarahkan anak ke pola asuh yang sesuai dengan karakternya. Pada usia antara 36-40 tahun menunjukkan bahwa orang tua telah mempunyai pengalaman sebelumnya dalam mengasuh anak, sehingga mereka bisa mnerapkannya mana yang sesuai. Mengetahui tahapan perkembangan pada anak sangat penting agar anak tidak mengalami keterlambatan, orang tua dengan usia yang lebih matang akan sabar dan lebih telaten untuk mengikuti secara baik perkembangan anaknya. Sehingga perkembangan anak terpantau dan bisa dideteksi secara dini jika mengalami keterlambatan.

Pada penelitian ini dapat dilihat juga dari segi pendidikan, berdasarkan tabel 1 menunjukkan prosentase tertinggi pendidikan terakhir orang tua yaitu SMA sebanyak 16 responden (42,1\%), pendidikan terakhir SMP sebanyak 11 responden $(29 \%)$, terdapat pula orang tua dengan pendidikan terakhir perguruan tinggi sebanyak 9 responden sedangkan pendidikan terendah yaitu SD sebanyak 2 responden (5,2\%).

Pendidikan dan pengalaman orang tua dalam perawatan anak akan mempengaruhi persiapannya dalam menjalankan pengasuhan. Banyak cara yang dapat dilakukan untuk menjalankan peran pengasuhan, antara lain terlibat aktif dalam setiap pendidikan anak. Hasil riset dari Sir Godfrey Thomson menunjukkan bahwa pendidikan diartikan sebagai pengaruh lingkungan attas individu untuk menghasilkan perubahan yang tetap atau permanen di dalam kebiasaan tingkah laku, pikiran dan sikap (Supartini, 2004:36).

Pendidikan orang tua sangat berhubungan dengan pola asuh yang diterapkan, orang tua yang berpendidikan rendah akan lebih kolot dan mendominasi anak karena kurangnya pengetahuan orang tua tentang tumbuh kembang anak. Orang tua dengan pendidikan rendah tidak tau bagaimana seharusnya cara pengasuhan yang tepat diberikan pada anak sesuai dengan tahapan perkembangan anak. Sedangkan orang tua dengan pendidikan yang tinggi akan lebih siap untuk mengasuh anak dan mereka banyak tau tentang cara pengasuhan anak yang akan ia terapkan di keluarga, orang tua akan lebih memperhatikan 
perkembangan anaknya setiap tahunnya. .

Berdasarkan uraian di atas dapat diketahui bahwa rendahnya pendidikan orang tua dapat mempengaruhi pengasuhan yang diterapkan pada anak, orang tua dengan pendidikan rendah maka pengetahuan tentang pengasuhan pun rendah sehingga mereka cenderung meniru pola asuh orang tua nya terdahulu dalam mengasuh anaknya.

\section{Perkembangan Bahasa Anak Prasekolah Usia 4-5 Tahun Di Tk An Nidhom Desa Bangsongan Kecamatan Kayen Kidul Kabupaten Kediri}

Berdasarkan hasil penelitian tentang perkembangan bahasa anak prasekolah usia 4-5 tahun yang dilakukan di TK An Nidhom, menunjukkan bahwa dari 38 responden anak prasekolah usia 4-5 tahun didapatkan hasil normal sebanyak 19 anak (50\%), 14 anak dengan skor suspec $(36,84 \%)$, dan sebanyak 5 anak $(13,16 \%)$ dengan skor untesable.

Fungsi bahasa dalam tahap perkembangan merupakan yang paling kompleks diantara tahap lainnya. Kemampuan bahasa bersama kemampuan pemecahan masalah koordinasi tangan-mata merupakan indikator paling baik dari ada atau tidaknya gangguan perkembangan intelektual pada anak. Kemampuan ini kemudian berkembang menjadi perkembangan kemampuan sosial dan adaptasi terhadap lingkungan sekitarnya. Kemampuan koordinasi tangan-mata penting dalam menilai tingkat perkembangan intelektual. Begitu juga dengan kemampuan bahasa, bukan hanya kemampuan komunikasinya yang meningkat juga kemampuan intelektualnya. Anak menggunakan kemampuan komunikasinya untuk bertanya, mencoba gagasan, memberi alasan, dan semakin mengerti akan dunianya. (Suririnah, 2010:105).

Sebagian besar responden anak prasekolah usia 4-5 tahun perkembangan bahasanya normal. Ada beberapa anak yang mengalami perkembangan suspec dan bahkan terdapat anak yang tidak bisa diuji (untesable). Anak prasekolah dengan perkembangan bahasa normal sebagian besar diasuh oleh orang tua dengan pola asuh demokratis,dengan responden sebanyak 12 orang $(63,16 \%)$ dimana terdapat keseimbangan pemikiran, sikap dan tindakan antara anak dan orang tua. Baik orang tua maupun anak mempunyai kesempatan yang sama untuk menyampaikan suatu ide, gagasan atau pendapat untuk mencapai suatu keputusan.

Disini terlihat anak ceria, mudah bergaul dengan temannya dan bisa berkomunikasi dengan orang lain karena diberi kebebasan dan rasa aman dari orang tua, anak merasa tertarik dengan lingkungan sekitarnya, anak seringkali banyak bertanya dan aktif mencari tahu sehingga mereka bisa mudah beradaptasi dengan lingkungannya. Pada perkembangan bahasa yang baik orang tua ikut berperan dalam memberikan stimulasi-stimulasi perkembangan bahasa setiap tahapan usianya. Sehingga anak aktif dan bisa berkomunikasi dengan baik. Mereka aktif bertanya, tentang kejadian disekitarnya, mereka juga bisa cepat beradaptasi dengan orang orang dilingkungannya. Karena dalam lingkungan keluarga anak terbiasa untuk mengungkapkan bendapatnya. Mereka selalu dimintai pendapat terkait dengan masalah yang menyangkut dirinya.

Walaupun demikian masih terdapat anak prasekolah usia 4-5 tahun yang mengalami perkembangan bahasa kategori suspec sebanyak 1 orang $(7,14 \%)$ dengan pola asuh orang tua otoriter, 6 orang anak $(42,86 \%)$ dengan pola asuh permisif dan 7 anak (50\%) dengan pola asuh demokratis. Pada skor untesable didapatkan pada anak prasekolah sebanyak 3 responden $(60 \%)$ dengan pola asuh otoriter dan 2 orang responden (40\%) dengan pola asuh permisif. 
Seorang anak yang mengalami keterlambatan berbicara mungkin terlambat pula secara umum pada aspek perkembangan lainnya. Kurangnya stimulasi bahasa bisa memperlambat perkembangannya, tetapi kehilangan stimulasi akan menyebabkan pengaruh yang sangat besar. Kurangnya stimulasi bahasa bisa dipengaruhi oleh pola asuh orang tua, orang tua kurang memperhatikan perkembangan bahasa, dan orang tua tidak tau bagaimana cara melakukan stimulasi perkembangan bahasa pada anaknya. (Tandry,2011:94).

Pada anak yang mengalami perkembangan suspec, anak terlihat sulit berinteraksi dengan teman-teman sebayanya, anak kesulitan untuk bisa berkomunikasi dengan temannya karena anak kesulitan untuk menyusun katakata agar bisa berkomunikasi dengan temannya. Mereka juga kurang mengerti apa yang dikatakan orang lain. Hal ini mungkin disebabkan karena pola pengasuhan orang tua yang cenderung membuat anak merasa takut atau tertekan. Sehingga anak cenderung pendiam dan sulit untuk berinteraksi dengan lingkungan sekitarnya. Sedangkan anak dengan kategori untesable bisa dikarenakan mereka menolak dilakukan pemeriksaan. Mereka merasa takut dan tidak nyaman. Sehingga memnengaruhi skor penilkaian. Anak takut bisa dikarenakan pola asuh orang tua, anak belum bisa mandiri. Mereka masih bergantung pada orang tua. Mereka tidak bisa lepas dari orang tua walaupun mereka telah berada pada lingkungan teman-temannya.

Hubungan Pola Asuh Orang Tua Dengan Perkembangan Bahasa Anak Prasekolah Usia 4-5 Tahun Di Desa Bangsongan Kecamatan Kayen Kidul Kabupaten Kediri.

Bila ditinjau kembali pada tabulasi silang antara pola asuh orang tua dengan perkembangan bahasa anak prasekolah usia 4-5 tahun pada tabel 6 terdapat 38 responden yang diteliti dimana orang tua dengan pola asuh demokratis sebanyak 19 responden (50\%) dan perkembangan bahasa anak normal sebanyak 19 responden (50\%). Dalam hal ini pola asuh demokratis dipengaruhi oleh beberapa faktor salah satunya adalah faktor pendidikan, dan umur. Prosentase tertinggi pendidikan terakhir orang tua adalah SMA dengan jumlah responden sebanyak 16 orang $(42,1 \%)$, sedangkan prosentase tertinggi umur responden adalah antara 36-40 tahun sebanyak 17 responden $(44,75 \%)$.

Berdasarkan analisa data dengan menggunakan chi square tentang hubungan antara pola asuh orang tua dengan perkembangan bahasa anak prasekolah usia 4-5 tahun, diperoleh hasil $x^{2}$ hitung sebesar 18,13 dengan $\alpha$ 0,05 . Oleh karena itu $x^{2}$ hitung lebih besar dari $x^{2}$ tabel $(18,13>9,49)$ hipotesa yang dibuat oleh peneliti yaitu H1 diterima, yang artinya ada hubungan antara pola asuh orang tua dengan perkembangan bahasa anak prasekolah usia 4-5 tahun.

Keluarga memiliki peranan yang sangat penting dalam upaya mengembangkan pribadi anak. Perawatan orang tua yeng penuh kasih sayang dan pendidikan tentang nilai-nilai kehidupan, baik agama maupun sosial budaya yang diberikannya merupakan faktor yang kondusif untuk mempersiapkan anak menjadi pribadi dan anggota masyrakat yang sehat. Hubungan ini dimaknai sebagai proses pengalaman berinteraksi dan berkomunikasi dengan lingkungan keluarga, terutama dengan orang tua yang mengajar, melatih dan memberikan contoh berbahasa kepada anak (Yusuf, 2012:121).

Hal ini menggambarkan pola asuh orang tua mempengaruhi perkembangan bahasa. Artinya anak yang mendapatkan pola asuh yang sesuai dari orang tuanya dan anak bisa menerima dengan baik pola asuh yang diberikan oleh orang tuanya maka perkembangan bahasa anak akan baik. Adapun macam-macam pola 
asuh yaitu otoriter, permisif dan demokratis. Pola asuh demokratis dikatakan paling sesuai dengan perkembangan anak. Karena pada pola asuh demokratis orang tua berusaha untuk menyatukan pendapat, pemikiran dan sikap dengan anak. Orang tua dengan pola asuh ini juga lebih mengajak anak untuk berdiskusi dan belajar memecahkan masalah secara bersama-sama. Jadi anak dilatih untuk berfikir didampingi orang tua dan menanyakan lagi pada orang tua tentang hasilnya.

Berbeda dengan 2 pola asuh lainnya yaitu permisif dan otoriter. Pada pola asuh otoriter orang tua cenderung menentukan keputusan secara sepihak tanpa meminta pendapat anak sehingga anak diminta untuk selalu menuruti keinginan orang tua. Pada pola asuh ini anak sering merasa tertekan dan takut yang berlebihan. Namun pada pola asuh ini orang tua akan memberikan perhatian lebih pada anaknya sehingga semua kegiatan yang anak lakukan akan terpantau.

Oleh karena itu orang tua harus memahami pola pengasuhan yang tepat untuk anaknya agar perkembangan bahasa anak bisa terpantau disetiap tahapannya. Orang tua juga harus bisa memberikan stimulasi untuk melatih perkembangan bahasa pada anak. Sehingga anak tidak mengalami keterlambatan perkembangan. Anak dengan perkembangan bahsa baik akan mudah berkomunikasi dengan lingkungannya terutrama teman-teman sebayanya, mudah berkomunikasi berarti anak tersebut mudah untuk berinteraksi dengan lingkungan, mudah bergaul dan mudah beradaptasi. Sehingga anak bisa mengembangkan segala potensi yang dimilikinya tanpa rasa takut dan tertekan.

\section{SIMPULAN}

1. Pola asuh orang tua di Tk An Nidhom Desa Bangsongan Kecamatan Kayen Kidul Kabupaten Kediri, sebanyak 19 responden $(50,00 \%)$ menggunakan pola asuh demokratis dalam mengasuh anaknya.

2. Perkembangan bahasa anak prasekolah usia 4-5 tahun di Tk An Nidhom Desa Bangsongan Kecamatan Kayen Kidul Kabupaten Kediri, sebanyak 19 anak $(50,00 \%)$ perkembangan bahasanya normal.

3. Dari hasil analisis uji chi square yang dilakukan diperoleh hasil $x^{2}$ hitung $(18,13)$ lebih besar dari $x^{2}$ tabel $(9,49)$ maka H1 diterima yaitu ada hubungan pola asuh orang tua dengan perkembangan bahasa anak prasekolah usia 4-5 tahun. 


\section{DAFTAR PUSTAKA}

Adrina, Dian. 2011. Tumbuh Kembang Dan Terapi Bermain Pada Anak. Jakarta: Salemban Medika

Arikunto, S. 2006. Prosedur Penelitian Suatu Pendekatan Praktik. Jakarta:Rineka Cipta

Hasan, Maimunah. 2010. PAUD (Pendidikan Anak Usia Dini). Jogjakarta: Diva Press

Hidayat, A. Alimul Aziz. 2010. MetodePenelitian Kebidanan Dan Teknik Analisis Data. Jakarta: Salemba Medika .(2010). Pengantar Ilmu Keperawatan Anak Jilid 1.Jakarta: Salemba Medika

Marmi Dan Kukuh. 2012. Asuhan Neonatus Bayi Dan Balita. Jakarta: Pustaka Pelajar

Notoadmojo, Soekidjo. 2012. Metodologi Penelitian Kesehatan. Jakarta: Rineka Cipta

Nursalam. 2005. Asuhan Keperawatan Bayi Dan Anak. Jakarta: Salemba Medika .(2011). Konsep Dan Penerapan Metoddologi Penelitian Ilmu Keperawatan. Jakarta: Salemba Medika

Papalia, Et Al. 2009. Human Development. Jakarta: Salemba Medika

$$
\text { (2010). Human }
$$

Development. Jakarta: Kencana

Patmonodewo, S. 2008. Pendidikan Anak Prasekolah. Jakarta:Rineka Cipta

Septiari, Beti B. 2012. Mencetak Balita Cerdas. Jogjakarta: Nuha Medika

Soetjiningsih. 2014. Tumbuh Kembang Anak. Jakarta: EGC
Sugiyono.2009. Metode penelitian, kuantitatif, kualitatif dan $R \& D$. Bandung: Alfabeta

\section{(2012). Statistik Untuk}

Penelitian. Bandung: Alfabeta

Suparmi, Yupi. 2005. Konsep Dasar Keperawatan Anak. Jakarta: EGC

Suwariyah, Puji. 2013. Test Perkembangan Bayi/Anak. Jakarta: TIM

Yusuf, Syamsu. 2011. Psikologi Perkembangan. Bandung: Rosda

Brojot(2011). Kuesioner Pola Asuh Orang tua. Diakses dari:http://brojotperawatindonesia.blogspot.com/2011/ 08/kuesioner-proposal-pola-asuhorangtua.html (diakses pada5april 2014)

Hayati, Sri. Kumboyono \& Rinik.2013. Hubungan Pola Asuh Orang Tua Dengan Perkembangan Bahasa Anak Usia Prasekolah. Diakses Dari : old.fk.ub.ac.id/srtikel/id/filedownload /keperawatan/sri\%20hayati.pdf (diakses pada 5 april 2014)

Judarwanto.2009.Angka kejadian gangguan bicara dan bahasa pada anak (online) diakses dari: http://childspeechclinic.wordpress.co m/2012/10/07/angka-kejadiangangguan-bicara-dan-bahasa-padaanak [diakses pada 5 april 2014].

Judarwanto (2012). Gangguan Bicara, Bahasa dan Gangguan Motorik. Diakses dari:http://childspeechclinic.wordpres s.com/2012/10/07/gang-bicarabahasa-dan-gangguan-motorik/ (diakses pada 5 april 2014).

Wikipedia. 2014. Orang tua (online) diakses dari: 
id.wikipedia.org/wiki/orang_tua2014

(diakses 6 april 2014 